\title{
Standardization of Screen Aperture Size for Processing of Seeds of Chilli (Capsicum annuum L.) Hybrid UARChH42 (JCH42)
}

\author{
Neha Thakur ${ }^{1 *}$, S.N. Vasudevan ${ }^{2}$, B.V. Tembhurne ${ }^{3}$, S.R. Doddagoudar ${ }^{1}$, \\ Sangeeta I. Macha ${ }^{1}$ and M.G. Patil ${ }^{4}$ \\ ${ }^{I}$ Department of Seed Science and Technology, AC, UAS, Raichur- 584104, Karnataka, India \\ ${ }^{2}$ ZARS, V.C. Farm, Mandya, UAS, Bangalore, Karnataka, India, 571405 \\ ${ }^{3}$ Department of Genetics and Plant Breeding, ${ }^{4}$ Department of Horticulture, AC, UAS, \\ Raichur- 584104, Karnataka, India \\ *Corresponding author
}

\section{A B S T R A C T}

\begin{tabular}{|l|}
\hline Keyw or d s \\
Chilli, Seeds \\
UARChH42, \\
Screen aperture size \\
\hline Article Info \\
\hline $\begin{array}{l}\text { Accepted: } \\
\text { 20 February } 2019 \\
\text { Available Online: } \\
\text { 10 March 2019 }\end{array}$ \\
\hline \hline
\end{tabular}

Present investigation was carried out in the Department of Seed Science and Technology, University of Agricultural Sciences, Raichur, Karnataka during kharif 2016 and 2017. Seeds were extracted from red dried harvested fruit and well dried chilli hybrid seeds were subjected to processing by using five different bottom screen aperture size viz., $0.90 \mathrm{~mm}$ oblong, $0.80 \mathrm{~mm}$ oblong, $1.80 \mathrm{~mm}$ round, $2.00 \mathrm{~mm}$ round and $2.10 \mathrm{~mm}$ round. The observations on seed recovery percentage, germination, seedling length, seedling vigour index were recorded. The screen aperture size $0.80 \mathrm{~mm}$ oblong recorded maximum seed recovery and $2.10 \mathrm{~mm}$ recorded maximum per cent germination and other seed quality parameters. Also significantly on par values of recovery per cent and other seed quality parameters with the highest values was recorded in $2.00 \mathrm{~mm}$ round sieve size and it was higher than as prescribed by Indian Minimum Seed Certification Standards. Thus, the bottom screen aperture size of $2.00 \mathrm{~mm}$ round can be recommended for processing the seeds of newly released CMS based chilli hybrid UARChH42 (JCH42)

\section{Introduction}

Chilli (Capsicum annuum L.) also known as pepper, is a member of solanaceae family and one of the most valuable fruit vegetables in the world. It is indigenous to South America and was first introduced to India from Brazil by Portuguese towards the end of fifteenth century. India is considered to be the secondary centre of diversity for chilli especially of $C$. annuum, the most important cultivated species. Chilli is grown all over the world for vegetable, spice, condiment, sauce and pickle. In India, chilli occupies an area of 311 thousand hectares with a production of 3761 thousand metric tonnes and productivity of 12.1 metric tonnes per hectare in 2017-18 (Anon., 2018). Among the most important states, Andhra Pradesh, Karnataka, Maharashtra and Tamil Nadu accounts for three-fourth of the total area. Karnataka state (2016-17) stands third in dried chilli crop area 
(102.30 thousand hectares) with a production of 103.20 thousand metric tonnes and productivity of (1.01 MT dried chilli/ha) (Anon., 2018).

In seed production programme of any crop, lack of good quality seeds may result in poor germination as well as field emergence. The deterioration of seed quality may be due to poor handling of seed after harvest that leads to poor and erratic field emergence and failure of seedling establishment in the field which subsequently results into lower productivity (Ganiger et al., 2018). Any seed lot when harvested includes seeds of different sizes and densities. This variation is because of differences between seeds harvested from different plants and partly due to differences among seeds borne at different times on the same plant. Seed size, to some extent is an inherited character; it is also influenced by mother plant nutrition, moisture availability to the developing seed and its position in the plant (Angadi and Kumar, 2016). Also seed development can be retarded by pest and disease attacks and seeds borne on poorly developed plants will be smaller. Therefore, it is required to process the seeds to elevate its planting value. Seed processing improves the quality of seed by discarding smaller, broken, chaffy, diseased seeds which have poor quality. Use of proper sieves for obtaining maximum seed recovery with higher seed quality is an important objective of seed processing. Therefore in view of above the importance of seed processing, present research was carried out to standardize the bottom screen aperture size for newly released chilli hybrid UARChH42 (JCH42) and further improving the quality of seed.

\section{Materials and Methods}

The research experiment was carried out in the laboratory of Department of Seed Science and Technology, University of Agricultural Sciences, Raichur, Karnataka during kharif
2016 and 2017. Freshly harvested seeds of chilli hybrid UARChH42 (JCH42) were dried to safe level of moisture and the seeds were cleaned by using top screen ( $4 \mathrm{~mm}$ round) and graded using five different bottom screen size viz., $0.90 \mathrm{~mm}$ oblong, $0.80 \mathrm{~mm}$ oblong, 1.80 $\mathrm{mm}$ round, $2.00 \mathrm{~mm}$ round and $2.10 \mathrm{~mm}$ round. The seeds that retained on the screen were collected separately and its recovery percentage and seed quality parameters viz., physical purity, germination, root length, shoot length, seedling dry weight and seedling vigour index were recorded. Recovery percentage was recorded by processing the hybrid seed on the above mentioned sieves separately and quantity of good seed retained on the sieve was weighed and recovery percentage was worked out by using the following formula.

$$
\text { Seed recovery }(\%)=\frac{\text { Weight of seeds retained over sieve }}{\text { Total weight of seeds used for processing }} \times 100
$$

Physical purity was recorded by taking five grams of seeds in four replicates in each treatment and separated into its components viz., pure seed, other crop seed, weed seed and inert matter. All the four components were weighed separately and percentage of pure seed was determined as per following formula;

Physical purity $(\%)=\frac{\text { Weight of pure seed }}{\text { Total weight of all components }} \times 100$

The germination test was conducted in four replicates of 100 seeds each by following between paper method and the rolled towels were incubated in the walk-in seed germination room maintained at $25 \pm 2{ }^{\circ} \mathrm{C}$ temperature and $90 \pm 5 \%$ RH (Anon., 2013). Seedling vigour index was calculated by multiplying germination (\%) and seedling length $(\mathrm{cm})$ (Abdul Baki and Anderson, 1973). Root length, shoot length and seedling dry weight was calculated as per International Rules for Seed Testing (Anon., 2013). The statistical analysis was carried out for each 
observed character under the study using MSExcel. The mean values of data for Completely Randomized Design (CRD) were subjected to analysis of variance as per the design of experiment as suggested by Gomez and Gomez (1984). The critical differences were calculated at one per cent level of probability wherever ' $F$ ' test was found significant.

\section{Results and Discussion}

Seed recovery was significantly affected by different sieve size with treatment $\mathrm{S}_{3}(1.80$ $\mathrm{mm}$ round) recorded significantly highest seed recovery (76.34 in 2016, 76.15 in 2017) (Fig. 1) because of less rejection due to retaining of seeds over the sieve, it was on par with $\mathrm{S}_{4}$ ( $2.00 \mathrm{~mm}$ round) (73.91 in 2016 and $74.13 \%$ in 2017). Whereas, $S_{1}(0.9 \mathrm{~mm}$ oblong $)$ recorded lowest seed recovery (61.99 in 2016, 62.48 in 2017) due to higher rejection of seeds (Table 1). The results are similar to that of Mathad et al., (2012) and Vasudevan et al.,
(2012) in eggplant, Lambat et al., (2017) in safflower. The screen aperture size significantly affected seed quality with maximum values recorded in $\mathrm{S}_{5}(2.10 \mathrm{~mm}$ round) of physical purity (98.84\% in 2017), germination (83.90 in 2016, $84.06 \%$ in 2017) (Table 1), root length (10.31 in 2016, 10.48 $\mathrm{cm}$ in 2017), shoot length (11.39 in 2016, $11.43 \mathrm{~cm}$ in 2017) (Table 2), seedling dry weight (3.48 in 2016, $3.52 \mathrm{mg}$ in 2017) which was on par with $\mathrm{S}_{4}$ (2.00 mm round) (Fig. 1). Also $\mathrm{S}_{5}$ (2.10 $\mathrm{mm}$ round) recorded higher seedling vigour index (1136 in 2016, 1169 in 2017) (Table 3) (Fig. 1).

This may be because of retention of bolder seeds on screen aperture size with optimum size which constitutes of higher physiological attributes within seeds; higher initial food reserves in the larger seed, greater embryo size, and more ability to utilize the metabolites that promoted better seed germination and other quality parameters

Table.1 Effect of screen aperture size of bottom screen on seed recovery, physical purity and germination of chilli hybrid UARChH42 (JCH42)

\begin{tabular}{|l|c|c|c|c|c|c|c|c|c|}
\hline \multirow{2}{*}{ Sieve size } & \multicolumn{3}{|c|}{ Seed recovery (\%) } & \multicolumn{3}{c|}{ Physical purity (\%) } & \multicolumn{3}{c|}{ Germination (\%) } \\
\cline { 2 - 11 } & 2016 & 2017 & $\begin{array}{c}\text { Pooled } \\
\text { mean }\end{array}$ & 2016 & 2017 & $\begin{array}{c}\text { Pooled } \\
\text { mean }\end{array}$ & 2016 & 2017 & $\begin{array}{c}\text { Pooled } \\
\text { mean }\end{array}$ \\
\hline $\mathbf{S}_{\mathbf{1}}$ & 61.99 & 62.48 & 62.23 & 98.62 & 98.65 & 98.63 & 66.50 & 67.30 & 66.90 \\
\hline $\mathbf{S}_{\mathbf{2}}$ & 63.92 & 64.11 & 64.01 & 98.65 & 98.65 & 98.65 & 65.15 & 65.76 & 65.45 \\
\hline $\mathbf{S}_{\mathbf{3}}$ & 76.34 & 76.15 & 76.24 & 98.43 & 98.42 & 98.43 & 72.30 & 73.92 & 73.11 \\
\hline $\mathbf{S}_{\mathbf{4}}$ & 73.91 & 74.13 & 74.02 & 98.60 & 98.54 & 98.57 & 81.49 & 82.41 & 81.95 \\
\hline $\mathbf{S}_{\mathbf{5}}$ & 66.79 & 67.65 & 67.22 & 98.95 & 98.84 & 98.89 & 83.90 & 84.06 & 83.98 \\
\hline Mean & 68.59 & 68.90 & 68.75 & 98.65 & 98.62 & 98.63 & 73.87 & 74.69 & 74.28 \\
\hline S. Em $\mathbf{\pm}$ & 0.61 & 0.55 & 0.40 & 0.11 & 0.02 & 0.05 & 0.96 & 0.50 & 0.45 \\
\hline CD @1 \% & 2.55 & 2.31 & 1.66 & NS & 0.09 & 0.21 & 4.00 & 2.07 & 1.86 \\
\hline
\end{tabular}

$\mathrm{S}_{1}=0.90 \mathrm{~mm}$ oblong; $\mathrm{S}_{2}=0.80 \mathrm{~mm}$ oblong; $\mathrm{S}_{3}=1.80 \mathrm{~mm}$ round; $\mathrm{S}_{4}=2.00 \mathrm{~mm}$ round; $\mathrm{S}_{5}=2.10 \mathrm{~mm}$ round 
Table.2 Effect of screen aperture size of bottom screen on root length and shoot length of chilli hybrid UARChH42 (JCH42)

\begin{tabular}{|c|c|c|c|c|c|c|}
\hline \multirow[t]{2}{*}{ Sieve size } & \multicolumn{3}{|c|}{ Root length (cm) } & \multicolumn{3}{|c|}{ Shoot length $(\mathrm{cm})$} \\
\hline & 2016 & 2017 & Pooled mean & 2016 & 2017 & Pooled mean \\
\hline $\mathbf{S}_{1}$ & 11.33 & 11.56 & 11.45 & 7.52 & 7.49 & 7.51 \\
\hline $\mathbf{S}_{\mathbf{2}}$ & 10.31 & 10.48 & 10.40 & 7.13 & 7.29 & 7.21 \\
\hline $\mathbf{S}_{\mathbf{3}}$ & 12.56 & 12.93 & 12.75 & 8.12 & 8.38 & 8.25 \\
\hline $\mathbf{S}_{4}$ & 15.00 & 13.91 & 14.45 & 10.24 & 10.44 & 10.34 \\
\hline $\mathbf{S}_{5}$ & 15.80 & 15.91 & 15.86 & 11.39 & 11.43 & 11.41 \\
\hline Mean & 13.00 & 12.96 & 12.98 & 8.88 & 9.01 & 8.94 \\
\hline S. Em \pm & 0.44 & 0.30 & 0.28 & 0.34 & 0.12 & 0.20 \\
\hline CD@1\% & 1.82 & 1.23 & 1.17 & 1.44 & 0.48 & 0.82 \\
\hline
\end{tabular}

$\mathrm{S}_{1}=0.90 \mathrm{~mm}$ oblong; $\mathrm{S}_{2}=0.80 \mathrm{~mm}$ oblong; $\mathrm{S}_{3}=1.80 \mathrm{~mm}$ round; $\mathrm{S}_{4}=2.00 \mathrm{~mm}$ round; $\mathrm{S}_{5}=2.10 \mathrm{~mm}$ round

Table.3 Effect of screen aperture size of bottom screen on seedling dry weight and seedling vigour index of chilli hybrid UARChH42 (JCH42)

\begin{tabular}{|l|c|c|c|c|c|c|}
\hline \multirow{2}{*}{ Sieve size } & \multicolumn{3}{|c|}{ Seedling dry weight (mg) } & \multicolumn{3}{|c|}{ Seedling vigour index } \\
\cline { 2 - 7 } & 2016 & 2017 & Pooled mean & 2016 & 2017 & Pooled mean \\
\hline $\mathbf{S}_{\mathbf{1}}$ & 2.33 & 2.40 & 2.36 & 1253 & 1283 & 1268 \\
\hline $\mathbf{S}_{\mathbf{2}}$ & 2.08 & 2.09 & 2.09 & 1136 & 1169 & 1152 \\
\hline $\mathbf{S}_{\mathbf{3}}$ & 2.60 & 2.46 & 2.53 & 1495 & 1575 & 1535 \\
\hline $\mathbf{S}_{\mathbf{4}}$ & 3.30 & 3.35 & 3.33 & 2057 & 2006 & 2031 \\
\hline $\mathbf{S}_{\mathbf{5}}$ & 3.48 & 3.52 & 3.50 & 2281 & 2298 & 2289 \\
\hline Mean & 2.76 & 2.76 & 2.76 & 1644 & 1666 & 1655 \\
\hline S. Em \pm & 0.06 & 0.07 & 0.04 & 50 & 28 & 31 \\
\hline CD @1 & 0.23 & 0.28 & 0.16 & 208 & 117 & 128 \\
\hline \% & & & & & & \\
\hline
\end{tabular}

$\mathrm{S}_{1}=0.90 \mathrm{~mm}$ oblong; $\mathrm{S}_{2}=0.80 \mathrm{~mm}$ oblong; $\mathrm{S}_{3}=1.80 \mathrm{~mm}$ round; $\mathrm{S}_{4}=2.00 \mathrm{~mm}$ round; $\mathrm{S}_{5}=2.10 \mathrm{~mm}$ round 


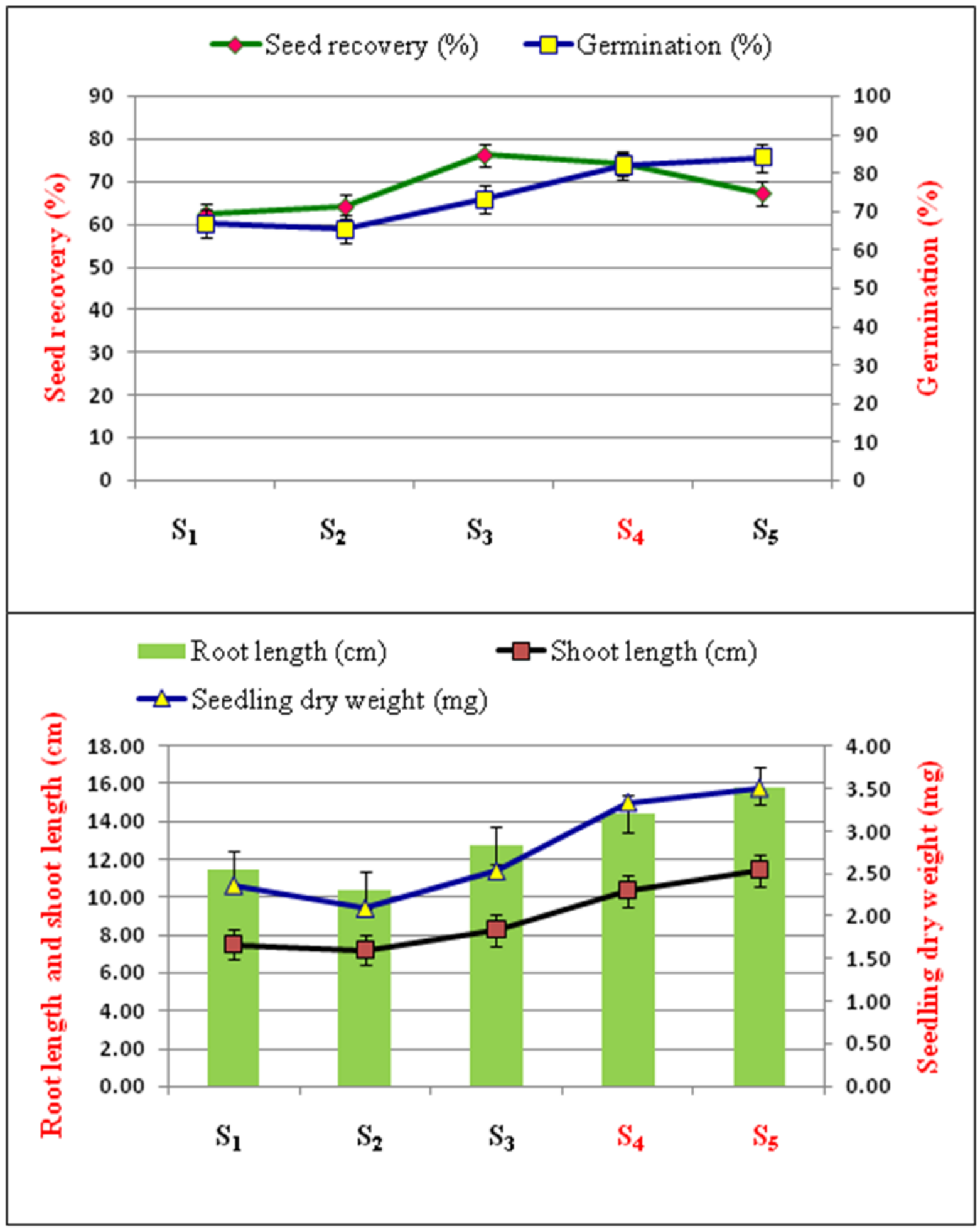

Fig. 1. Graphical representation of effect of screen aperture size of bottom screen on seed recovery and seed quality par ameters in CMS based chilli hybrid 
Similar results were observed by Kumar et $a l$. , (2014) in green gram, Angadi and Kumar (2016) in fodder sorghum, Lamani and Deshpande (2017) in onion and Ganiger et al., (2018) in soybean. With the reduction in sieve size i.e. $\mathrm{S}_{3}(1.80 \mathrm{~mm}$ round $)$ treatment recorded lower values of physical purity (98.42 \% in 2017), germination (65.15 in $2016,65.76 \%$ in 2017 ), root length (10.31 in $2016,10.48 \mathrm{~cm}$ in 2017), shoot length (7.13 in 2016, $7.29 \mathrm{~cm}$ in 2017), seedling dry weight (2.08 in 2016, $2.09 \mathrm{mg}$ in 2017).

From this study it can be inferred that the per cent germination recorded in both $2.10 \mathrm{~mm}$ and $2.00 \mathrm{~mm}$ round treatment was higher than the Indian Minimum Seed Certification Standards and also $2.00 \mathrm{~mm}$ sieve had more seed recovery per cent values as well as all the seed quality parameters than $2.10 \mathrm{~mm}$ and other sieve size. Hence, it can be inferred that the $2.00 \mathrm{~mm}$ round sieve can be considered optimum for processing of chilli hybrid UARChH42 (JCH 42) seeds to obtain highest seed recovery, with requisite physical purity, germination, seedling length and seedling vigour index.

\section{References}

Abdul-Baki, A. A. and Anderson, J. D., 1973, Vigour determination by multiple criteria. Crop Sci., 13: 630-637.

Angadi, A., and Kumar, V., 2016, Standardization of sieve sizes for size grading in perennial fodder sorghum. $J$. Farm Sci., 29(1): 103-105.

Anonymous, 2013, International rules for seed testing. Seed Sci. \& Technol., 24 (Supplement): 23-46.

Ganiger, B. S., Gowda, B., Lokesh, G. Y. and Lokesh, K., 2018, Studies on sieve size for grading of soybean cv. DSB 21 seeds. Int. J. Curr. Microbiol. App. Sci., Special Issue-6: 1208-1213.

Gomez, K. A. and Gomez, A. A. 1984, Statistical procedure for agricultural research. New York: John Wily. 690 Pp.

Kumar A., Jakhar S. S., Mor V. S., Sangwan V. P., Singh V. K., 2014, Standardization of sieve size for grading green gram (Vigna radiata $\mathrm{L}$.) seeds. $J$. Food Leg., 27(3): 258-260.

Lamani, K. and Deshpande, V. K., 2017. Effect of different seed processing methods on seed recovery and seed quality of onion cv. Arka Kalyan. Int. J. Pure App. Biosci., 5(5): 644-648.

Lambat, P., Babhulkar, V., Gadewar, R., Charjan, S., Lambat, A., Parate, R. and Dhapke, S., 2017, Effect of seed size on germination and seedling vigor in safflower. Intern. J. Res. Biosc. Agric. Tech., 2: 1-2.

Mathad, R. C., Vasudevan, S. N., Patil, S. B. and Lokeshappa, B. L., 2012, Precision seed sorting to improve hybridity in eggplant. Seed Tech., 34(2): 245-248.

Vasudevan, S. N., Mathad, R., C., Patil, S. B., Lokeshappa, B. L. and Doddagoudar, S. R., 2012, Influence of seed conditioning to improve genetic purity in eggplant. $2^{\text {nd }}$ International Conference on Environmental and Agriculture Engineering IPCBE, 37: 100-103.

\section{How to cite this article:}

Neha Thakur, S.N. Vasudevan, B.V. Tembhurne, S.R. Doddagoudar, Sangeeta I. Macha and Patil, M.G. 2019. Standardization of Screen Aperture Size for Processing of Seeds of Chilli (Capsicum annuum L.) Hybrid UARChH42 (JCH42). Int.J.Curr.Microbiol.App.Sci. 8(03): 2362-2367. doi: https://doi.org/10.20546/ijcmas.2019.803.279 